\title{
Youth policy in the human capital management system: Russian practice
}

\author{
Daria Maltseva ${ }^{1, *}$, Olga Safonova $^{1}$, Anastasia Dedul ${ }^{1}$, Maria Petrunina ${ }^{1}$, and Sofia Tepina ${ }^{2}$ \\ ${ }^{1}$ St. Petersburg State University, St. Petersburg, Russia \\ ${ }^{2}$ Secondary general education school № 316 with in-depth study of the English language, St. \\ Petersburg, Russia
}

\begin{abstract}
The study analyzes the modern youth policy of the Russian Federation using the methodological foundations of the theory of human capital. In this context, the criteria for the efficiency of youth policy are defined. The authors argue that youth policy is one of the priority areas of activity that determines the improvement of the country's human capital. Moreover, it is possible to designate the formation and development of well-rounded young people who demonstrate initiative, are responsible and patriotic, have an active civic position, beliefs and a system of values, and take an active part in political and public life.
\end{abstract}

\section{Introduction}

Today, in any modern state, youth is a strategically important social group, and the formation and accumulation of human capital and the society as a whole depends on its resources management. As United Nations Secretary General, António Guterres, said: "Peace, economic dynamism, social justice, tolerance, all these and more depend on tapping into the potential of youth" $[1,2]$. Above-mentioned priorities set the vector for the development of youth policy strategies, which have to become a system for the reproduction of world-class human capital, create added value in the economy, and play a transformative role.

Despite the fact that Russia has already accumulated some experience in strategic youth management, a number of problems still remain unresolved: the lack of methodological recommendations necessary for the development and implementation of strategic documents on state youth policy; gaps in youth policy legislation; insufficient coordination of practices and projects aimed at accumulating the country's human capital, etc.

This makes it necessary to analyze the existing legislation in the field of state youth policy, the experience of its implementation, as well as innovative development projects in assessing the impact on the effectiveness of human capital development.

\footnotetext{
* Corresponding author: buenafiesta@mail.ru
} 


\section{Materials and methods}

In recent years, youth policy has become an extremely popular subject of academic research. However, the range of topics covered in this subject area is very limited, which determines the high degree of relevance of this analysis. The main purpose of this study is to examine the existing mechanisms for implementing youth policy, as well as to develop recommendations to public authorities on its harmonization and optimization.

The key feature of the research methodology is the combination of scientific principles and theoretical approaches that allow us to characterize all the variety of processes and effects of the state youth policy implementation in the modern world, primarily in the sphere of human capital management.

The scientific foundation for this article consists of the main methodological developments of the comparative approach, which is used for a comparative analysis of the implemented state programs, innovative projects and practices in the field of state youth policy, as well as statutory instruments. In particular, the study included a thorough analysis of the main regulatory document that defined the key goals and main provisions of the state youth policy in the interests of the state and society at the present stage: the Decree of the Government of the Russian Federation No. 2403-p On Approval of the Fundamentals of the State Youth Policy of the Russian Federation for the Period up to 2025 dated November 29, 2014 [4].

The socio-cultural approach made it possible to study the relationship between the interpretations of youth as the main driver of the accumulation and intensification of human capital and the cultural, historical, political and social specifics of the state $[2,3,6]$. The competence-based approach was used in this article to determine the main directions of youth development strategies and to assess the regulatory impact of state programs and initiatives in this area.

The methodology of neo-institutionalism used in the study makes it possible to analyze in detail the possibilities of combining the efforts of the state and business in the direction of modernization of youth policy in the context of digital transformations of the management process at all levels [1].

The risk management methodology made it possible to identify both the most effective and potentially hazardous scenarios for the youth policy implementation in the context of digitalization, as well as to assess the effectiveness of state policy in the field of human capital development, to describe the specifics of the interaction process between state and non-state organizations in this area $[1,6]$.

\section{Results and discussion}

In the course of the analysis conducted, it was proved that the most significant positive effects of the Russian youth policy were shown in the implementation of projects to support talented youth.

Within the framework of the presented research, a fundamental analysis of current projects and initiatives in the area of state youth policy was conducted. During the study, the following strategic directions of program implementation were identified: 1) education; 2) civic and patriotic upbringing; 3) personnel policy; 4) entrepreneurship.

The analysis showed that today in Russia the existing state activities/projects in education, such as "All-Russian Academic Olympics for School Students", "Tavrida", "The Territory of Meanings", "Russia Is a Country of Opportunities", "Sirius", "I'm a Professional", and others are aimed at the identification of the talented youth at the earliest age possible, its further development and professional support by the creation of conditions for the development of their intellectual and personal potential, participation in the 
education of potential future leaders of the country [7,8]. Most of the projects are implemented throughout Russia, which allows to create equal starting opportunities for people from different regions, as well as to help them to use their innovative potential in the economic and political spheres.

The abundance of youth events, especially in the field of education, reflects the need of the state and society for professional, highly qualified domestic personnel able to lead the management system in various industries in the future.

The next important area of implementation of the state youth policy is patriotic education. One of the most striking manifestations is the creation of the Rospatriot Center (the Russian Center for Civic and Patriotic Education of Children and Youth). Among the main activities supported by the Federal Agency for Youth Affairs are the following: coordination of the implementation of the state program "Patriotic Education of Citizens of the Russian Federation for 2016-2020" [4,9], as well as the program of patriotic education of young people. This activity covers a wide range of spheres of society's life, uniting and coordinating interaction between military and patriotic associations, military units and veteran organizations, and is aimed at creating a value orientation among young people, including a sense of responsibility for the fate of the state and a positive attitude to public service and military service. In practice, this initiative is manifested in an increase in the number and higher activity level of search parties, military history clubs, associations of Cossack youth, etc.

In addition to the support for talent and proactive young people, as well as patriotic education, the presented study recorded an extremely high interest of the Russian state in the future leaders and managers. The development of the most successful personnel requires not only an advanced educational system, but also support for proactive candidates at the first stage of their professional development. One of the most urgent problems of modern youth is its indifferent position and passive attitude to public life. About half of young people do not see the point in exercising their civil and political rights: they do not participate in the elections, they are indifferent to changes in the political situation in the country, and do not demonstrate any civil initiative $[10,11]$. In the context of underdeveloped civil society and local self-government, this situation seems logical. But if young people do not take part in the political life of the society, are not interested in governance, then it is extremely difficult to make significant state decisions, develop business and the economy, strengthen the country's position in the international arena. Therefore, the task of the state and socio-political organizations is to create conditions for increasing the political and economic interest and activity of young people, attract them to state development and to the development of the economic sector. One of the most prominent examples of state initiatives in this area is the creation of youth branches of political parties: Molodaya Gvardiya ("the Young Guard", the United Russia), the LDPR Youth Organization, and others. Leaders are in demand not only in the sphere of political governance, but also in the economy and business. That is why modern state policy is aimed at supporting business and micro-entrepreneurship. The economy is the engine of the country's development, bringing funds to the budget, ensuring the influence of the state in the international arena. Russian legislation provides additional guarantees for young entrepreneurs, but in practice these initiatives have been implemented only marginally. My First Business project for participants aged 14 to 23 seems to be effective in introducing young people to economic activity. The successful completion of the project not only gives young people the opportunity to show their potential once, but also lays the foundations for further participation in state youth support programs. The need to support youth entrepreneurship was also established in the above-mentioned Government Decree on Approving the Foundations of the State Youth Policy in the Russian Federation up to 2025. 
In the course of the analysis conducted, it was found that effective implementation of support for youth entrepreneurship requires harmonization of three strategic aspects. The first is the legislative aspect: the adoption of a single regulatory act at the federal level to establish clear criteria for identifying young entrepreneurs, as well as guarantees provided to them by the state. The second is educational, which includes the need to develop educational programs for the development of entrepreneurial thinking, planning and business management, strengthening the connection between educational organizations and existing entrepreneurs in order to synthesize practical and theoretical knowledge and skills. The third aspect is economic, which requires the liberalization of economic activity. The latter can be considered as one of the most difficult to implement, since it must take into account the public interest in state control, the degree of state intervention in the economy, as well as the freedom of entrepreneurial activity and the market economy $[11,12]$. In addition to the economic goal, the support for youth entrepreneurship will ensure the development of centers for youth innovative creativity, as well as the spread of educational programs on technological entrepreneurship.

It is obvious that the modern processes of growing global crises and rapidly developing digital transformations have significantly changed the approaches to the study of youth policy in the human capital management system and created new tasks for the public administration in this area.

The modern history of the formation of youth policy in the Russian Federation began in 1992 with the adoption of the Decree of the President of Russia On priority measures in the field of state youth policy $[6,13,14]$ and the Resolution of the Supreme Council of the Russian Federation of 1993 On the main directions of state youth policy in the Russian Federation [15]. The documents became one of the first statutory instruments of the independent Russian Federation aimed at regulating youth policy. The decree provided for the creation of a National Council of Youth Associations, the development of international youth cooperation, and also reestablished state support, including material support. It was supposed to allocate funds not only from the federal budget, but also from the budgets of the corresponding regions to finance a part of youth programs and projects, and there was also an option of issuing long-term loans to young families. At the same time, the provisions of the Decree were aimed at solving the most acute social problems: child neglect and juvenile delinquency. Further, in order to provide socio-economic support for young people in the Russian Federation, in 1996 the Government adopted a resolution On Additional Measures to Support Young People in the Russian Federation [7,8,9].

The fate of the draft law On the Basics of State Youth Policy in the Russian Federation, initiated by deputies of the State Duma of Russia in 1998 is of interest [15]. After a lengthy debate, the draft law On the Basics of State Youth Policy in the Russian Federation adopted in the third reading in July 1999 was rejected by the Federation Council as insufficiently elaborated, declarative, containing general provisions and "expensive" for the country's budget ( 90 billion rubles for the period of three years). A conciliation commission was established and as a result, the agreed version was approved by both chambers in October 1999. In November 1999, the President of the Russian Federation (B.N. Yeltsin) vetoed the law; this does not happen very often at present, but then, in the period from 1995-1999, President Yeltsin used the right of veto 123 times. In July 2000, the State Duma considered the law again, but after a heated debate and a roll-call vote, it did not overcome the president's veto. In 2004, the law On the Fundamentals of State Youth Policy in the Russian Federation was withdrawn from consideration.

The third (from 1994) Federal Target Program "Youth of Russia (2001-2005)" approved by the decree of the Government of the Russian Federation was aimed at creating and developing legal, economic and organizational conditions for fostering civic awareness among young people in the context of a democratic society, a market economy and the rule 
of law, personal fulfillment of young people as active participants in the transformations of modern Russian society [16].

The next document which the Government intended to regulate the sphere of youth policy was "The Strategy of State Youth Policy in the Russian Federation" adopted in 2006. It was developed for the period up to 2016 and contained a set of priority areas and tasks related to young people, including the use of the subject-to-subject approach, when young people directly participated in the implementation of national projects [17]. Despite the fact that some lawyers and sociologists noted that the document was the main act regulating relations between the state and the youth, this statement seems controversial, since the proposed measures were of advisory nature. It was this decree of the Government that was replaced in 2014 with the "Fundamentals of the State Youth Policy of the Russian Federation for the Period up to 2025".

An important milestone in the evolution of youth policy was the approval by the Government of the Russian Federation of the "Concept of Long-Term Socio-Economic Development of the Russian Federation for the Period up to 2020". The ninth section of the Concept is devoted to youth policy, which is reflected in its name. The document provides a more detailed description of the goal of the socio-economic aspect of the state youth policy, which is to create, with the help of modern financial and economic tools, "conditions for successful social engagement and effective personal fulfillment of young people, the development of the potential of young people and its use in the interests of innovative development of the country"[4].

The conducted analysis has demonstrated that today the Russian legal system is characterized by the fragmented set of legislative acts of various nature and levels, and without the harmonization of such acts, as well as without the intensification of the most effective scenarios of state youth policy, its regulation seems extremely difficult. The existing statutory instruments regulate a very narrow sphere, namely, the issues of supporting talented youth and military and patriotic education. The study found that in order to solve this problem, it is necessary to consolidate in a single legislative act the powers of federal bodies, such as the Government of the Russian Federation, the Ministry of Science and Higher Education of the Russian Federation, the Ministry of Culture of the Russian Federation, the Ministry of Education, the Ministry of Sports and the Federal Agency for Youth Affairs, as well as to establish the jurisdictions of the regional authorities. The powers of the Government should include the establishment of the general foundations of the state youth policy, as well as providing funding and preparing the budget for this industry. It seems reasonable to entrust the Federal Agency for Youth Affairs the implementation of specific programs and projects in all regions of the country, while the ministries, according to their competence area, after conducting research, will be able to determine standards and regulations on their basis, develop response and interaction measures. At the same time, the authorities of the regions should not be deprived of the opportunity to implement the main goals and objectives. At the regional level, the support will be most effective in adopting laws of a particular region, promotion of local youth initiatives and provision of more guarantees in addition to federal ones.

Thus, it can be concluded that the reform in the sphere of youth policy, which is of particular importance for the nation-wide development and intensification of human capital, requires an integrated and systematic approach with the priority of legal support and regulation.

\section{Conclusion}

Today, the state is fully aware of the importance of creating conditions for the development of the human capital of the younger generation. The lack of state attention and support over 
a long period damaged the mechanisms of implementation, and the collapse of the previous political system destroyed the patterns of interaction between the state and the youth. A vast layer of socio-political institutions and organizations disappeared, as well as party-based social elevators that offered promotion for talented and proactive leaders. This led to general aging of the political system simply due to the lack of young talent to replace the current cadre. The risks involved in this are already known from historical experience: these are the stagnation of the political system, which results in passive attitude of young people, their disillusionment with the authorities, and, consequently, a crisis of legitimacy and an increase in protest sentiment.

The current policy of the Russian Federation is aimed at restoring the mechanisms of state support for young people, creating a regulatory framework for their effective implementation and reviving the initiative and civic interest of the younger generation.

For a fruitful solution to the problem of young people's human capital management, it is necessary, first of all, to ensure effective legal regulation of the process, which should not be reduced to casuistics, but also must not leave wide gaps, since this will create lack of legal clarity and lead to potential abuse and discrimination. Having worked out all aspects of youth policy, it is recommended to adopt legislation that clearly distinguishes the powers assigned to the jurisdiction of the Russian Federation and to the jurisdiction of the regions. Competent distribution will promote most effective implementation of the goals and objectives set, allocate the funds of the relevant budget appropriately, without creating an excessive burden on the systems of government authorities. It is also necessary to provide for potential sanctions for specific violations of the established procedure for implementing state policy, since in practice the absence of sanctions creates an impression that it possible to violate it with impunity. It is also necessary to preserve a certain autonomy of the regions, giving them the opportunity to establish additional guarantees, as well as to implement policies taking into account the specifics of the region (the standard of living, the main ethnic groups).

In addition to the development of legislation, it is necessary to ensure broad access of young people to the provided opportunities. Despite the success of projects to support talented youth, one of the main problems is that certain groups of the population do not have information about the existence of opportunities provided by the state. Therefore, it is often impossible to participate in forums, competitions and projects due to the lack of information on these initiatives and insufficient popularization thereof. This creates the need for marketing youth activity with the involvement of mass media and educational organizations of all levels. By obliging organizations to inform students about the existing opportunities to participate in events will make it possible to attract the largest number of young people.

It should also be noted that for a more effective youth policy, it is necessary to involve public and private organizations in this work. Well-developed social movements, especially those related to history and patriotic education (People's Memorial Books, the Immortal Regiment) will complement state policy and contribute to the development of an active civil policy not only for young people, but also for society as a whole. Private organizations, among other things, will make a great contribution to supporting youth entrepreneurship and scientific and technical projects. For example, during forums and competitions dedicated to new technologies, they will be able to conclude profitable contracts with those who have submitted promising projects, thereby developing their production and contributing to the implementation of state programs.

Thus, the article proved that youth policy is one of the highest priority areas of state activity that determine the improvement of the national human capital. As its ultimate goal, it is possible to designate the formation and development of well-rounded young people 
who demonstrate initiative, are responsible and patriotic, have an active civic position, beliefs and a system of values, and take an active part in political and public life.

\section{Acknowledgments}

The reported study was funded by RFBR and EISR according to the research project № 21011-33045.

\section{References}

1. L. Bennett, S. Livinston, European J. of Communication, 33(2), 122 (2018)

2. T. V. Sheludyakova, Levels of implementation of state youth policy in Russia: problems of delineation of powers, 8 (2017)

3. T. V. Sheludyakova, Social support of youth in the constituent entities of the Russian Federation: legal regulation and implementation practice, 12 (2014)

4. The Decree of the Government of the Russian Federation No. 2403-p On Approval of the Fundamentals of the State Youth Policy of the Russian Federation for the Period up to 2025 dated November 29, 2014, http://www.consultant.ru/

5. Strategy of the State Youth Policy in the Russian Federation" dated 18.12.2006 No. 1760-p (as amended on 16.07.2009), http://www.consultant.ru/

6. S. Guriev, D. Treisman, J. of Economic Perspectives, 33(4), 10 (2019)

7. On Priority Measures in the Field of State Youth Policy. Decree of the President of the Russian Federation No. 1075 dated 16.09.1992, http://www.kremlin.ru/

8. S. N. Pershutkin, The role of the President of Russia in disassembling and implementing the state youth policy: Normative and legal framework, ways and norms of activation, 31 (2007)

9. N. P. Tsukanova, Legal regulation of state youth policy in Russia, 92 (2014)

10. N. A. Samokhvalov, Implementation of state youth policy as an element of modernization of Russian statehood at the present stage, 3 (2015)

11. F. Kh. Tsalikova, Implementation of the state youth policy: on the example of the Republic of North Ossetia-Alania, 125 (2014)

12. M. V. Vavilin, Prosecutor's supervision over the implementation of laws in the field of patriotic education of youth as one of the priority directions of prosecutorial activities, 11 (2017)

13. V. I. Lenin, «Tasks of Youth Unions» III All-Russian Congress of the Russian Communist Youth Union (Moscow, 1920)

14. I. M. Ilyinsky, Art, NRC VKSH at the Central Committee of the Komsomol, 18 (1987)

15. On priority measures in the field of state youth policy: Decree of the President of the Russian Federation dated September 16, 1992 No. 1075 (as amended on April 12, 1999). - SPS "ConsultantPlus"

16. On the main directions of state youth policy in the Russian Federation: Resolution of the Supreme Soviet of the Russian Federation of July 3, 1993 No. 5090-1. - SPS "ConsultantPlus"

17. On state youth policy in the Russian Federation: Draft Federal Law of 08.05.2007 N 428343-4. - SPS "ConsultantPlus 